\title{
Genetic Evaluation for Yield and Yield Attributes in Garden pea (Pisumsativum var.hortense L.) under North Indian Gangetic Plain Conditions
}

\author{
Sana Afreen, Anand Kumar Singh, Durga Prasad Moharana*, \\ Vaibhav Singh, Pushpendra Singh and Bhagat Singh
}

\author{
Department of Horticulture, Institute of Agricultural Sciences, Banaras Hindu University, \\ Varanasi- 221005 (U.P.), India \\ *Corresponding author
}

\section{A B S T R A C T}

\begin{tabular}{l} 
Ke y w or d s \\
Heritability, \\
Phenotypic \\
coefficient of \\
variation, Genotypic \\
coefficient of \\
variation, \\
Garden pea. \\
\hline Article Info \\
\hline $\begin{array}{l}\text { Accepted: } \\
\text { 24 January } 2017 \\
\text { Available Online: } \\
\text { 10 February } 2017\end{array}$ \\
\hline
\end{tabular}

The present investigation was carried out to estimate phenotypic and genotypic coefficient of variation, heritability (broad sense), genetic advance and genetic gain for 15 quantitative traits in 21 different genotypes of Garden pea during Rabi2011-12 at Vegetable Research Farm, Institute of Agricultural Sciences, Banaras Hindu University, Varanasi (U. P.). Significant differences among the genotypes were observed for all the characters under study. Mean performance recordings showed genotype VRP-38 has earliest flowering, VRP-3 has maximum number of primary branches, VRP-7 for pod yield and VRP-372 recorded maximum seed yield. The PCV and GCV values were high for plant height, seed weight per pod and number of primary branches per plant. High heritability and moderate genetic gain was observed for characters like days to $50 \%$ flowering, days to $100 \%$ flowering, length of garden pea pods and width of garden pea pods. This indicated the influence of non additive gene action and environment in the expression of these traits.

\section{Introduction}

Garden pea (Pisum sativum var. hortense L.), belongs to leguminosae family, is one of the most popular vegetable crop grown all over the world, both for fresh market and the food processing industry. It has a prominent place among vegetables due to its high nutritive value, particularly proteins and other health building substances like carbohydrates vitamin $\mathrm{A}$, vitamin $\mathrm{C}$, calcium and phosphorus. It is grown commercially as a winter crop in the northern Indian plains and as a summer crops in the high hills. It is one of the most popular off season vegetable crops grown in north-western Himalayan region in India. For development of effective breeding programme and efficiency of selection largely depends upon the magnitude of significant variability present in a plant population.

The study of genetic parameters like genotypic and phenotypic coefficient of variation, heritability, genetic advance and genetic advance as per cent of mean provide a clear data about extent of variability present in a plant population and a relative measure of efficiency of selection of genotypes based on 
phenotype in a highly variable population. The present investigation was carried out to ascertain magnitude and extent of genotypic and phenotypic coefficient of variation, heritability, genetic advance and genetic advance as per cent of mean in 21 different genotypes for 15 traits under Varanasi conditions.

\section{Materials and Methods}

The experimental material comprises of 21 different genotypes of garden pea collected from Indian Institute of Vegetable Research, Varanasi. The experiment was carried out at Vegetable Research Farm, Institute of Agricultural Sciences, Banaras Hindu University, Varanasi (U.P.) duringRabi season of 2011-2012. The experiment was laid out in Randomized Complete Block Design (RBD) with three replications and plants were spaced at $30 \mathrm{~cm}$ distance between rows and $8 \mathrm{~cm}$ distance between plants with in a row. Cultural and agronomic practices were followed as per the standard recommendations and need based plant protection measures were taken up to maintain a healthy crop stand.

Observations were recorded on five competitive plants excluding border plants in each replication of each genotype for 15 traits viz., days to $1^{\text {st }}$ flowering, days to $50 \%$ flowering, days to $100 \%$ flowering, length of pod $(\mathrm{cm})$, width of pod $(\mathrm{cm})$, number of primary branches per plant, plant height $(\mathrm{cm})$, number of seeds per pod, average pod weight (g), number of pods per plant, seed weight per pod $(\mathrm{g})$, seed yield per plot $(\mathrm{g})$, seed yield per hectare $\left(\mathrm{q} \mathrm{ha} \mathrm{h}^{-1}\right)$, pod yield per plant $(\mathrm{g})$ and pod yield per hectare $\left(\mathrm{q} \mathrm{ha}{ }^{-1}\right)$.

The mean for each trait over 3 replications was computed for each genotype and analysed statistically. Both the genotypic and phenotypic coefficient of variance were estimated using the formula given by Burton
(1952), heritability (broad sense) was estimated as the ratio of genotypic variance to the total of phenotypic variance as suggested by Lush (1949) and genetic advance and genetic advance as per cent of mean were estimated by using the method suggested by Johnson et al., (1955).

\section{Results and Discussion}

The results of Analysis of Variance for 15 traits in 21 different genotypes of garden pea were presented in table 1 . Results indicated highly significant differences among the genotypes for all the characters indicating presence of sufficient amount of variability in all the characters studied.

The mean performance for 15 characters of 21 genotypes of garden pea was presented in table 2. On the basis of mean performance; the genotype VRP-38 is earliest in flowering. Genotypes VRP-61, VRP-284 and VRP-392 are good for plant height. For obtaining the maximum number of primary branches per plant, genotype VRP-3 is best. VRP-195, VRP-3, VRP-241 and VRP-48 are found promising for number of pods per plant. For better pod length, genotypes PC-531, AP-1 and Pant Uphar are good, whereas, the genotypes AP-1, VRP-82 and VRP-196 are good for pod width. The mean performance of genotypes VRP-7, VRP-284, Pant Uphar and VRP-248 is best for average pod weight. For high seed weight per pod, genotypes VRP248, AP-1 and PC-531 has been selected. VRP-7, VRP-241 and VRP-196 are found promising for pod yield whereas VRP-372, VRP-48, VRP-196 and VRP-392 have been used as a source for high seed yield.

While, studying the phenotypic coefficient of variation (PCV) and genotypic coefficient of variation $(\mathrm{GCV})$ it was observed that the magnitude of PCV was higher than GCV for all the traits under study suggesting the role of environmental variance (Table 3 ). 
Int.J.Curr.Microbiol.App.Sci (2017) 6(2): 1399-1404

Table.1 Analysis of Variance (ANOVA) of 21 genotypes of garden pea for 15 characters

\begin{tabular}{|c|c|c|c|c|c|c|c|c|c|c|c|c|c|c|c|c|}
\hline \multirow[b]{2}{*}{ 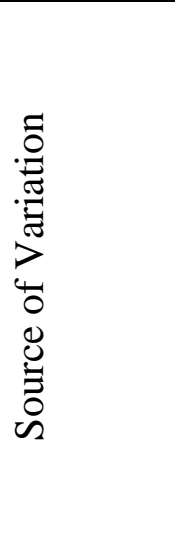 } & \multirow[b]{2}{*}{ 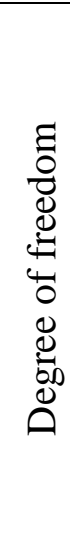 } & \multicolumn{15}{|c|}{ Mean Sum of Squares } \\
\hline & & 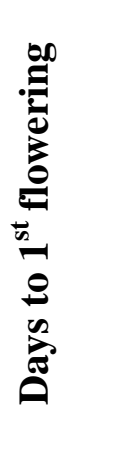 & 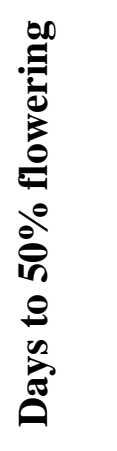 & 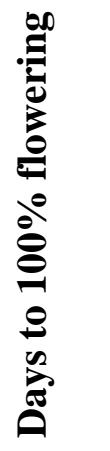 & 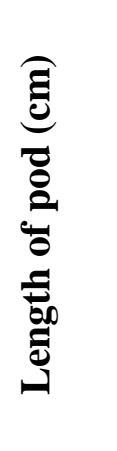 & 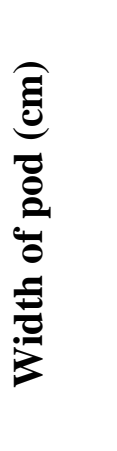 & 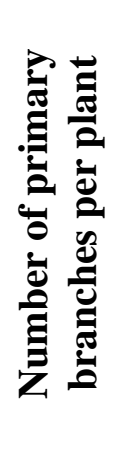 & 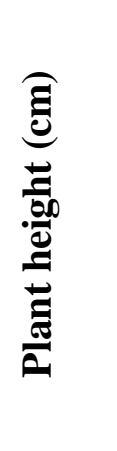 & 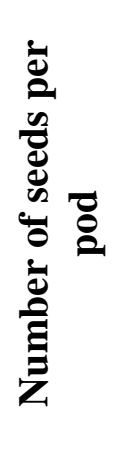 & 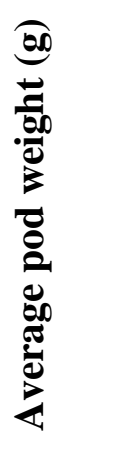 & 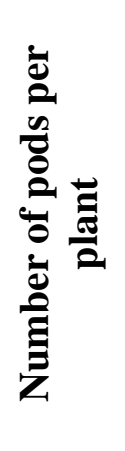 & 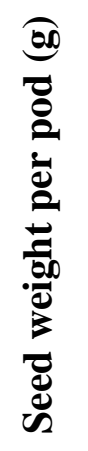 & 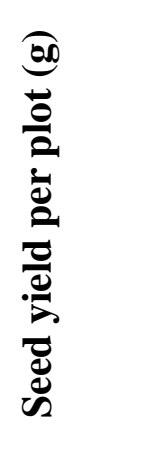 & 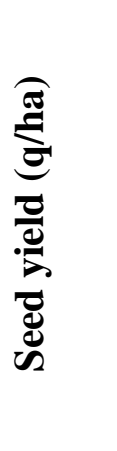 & 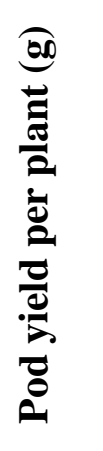 & 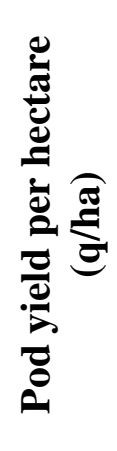 \\
\hline Replication & 2 & 6.33 & 2.04 & 0.39 & 0.26 & 0.00 & 0.07 & 36.04 & 0.52 & 0.25 & 0.40 & 0.44 & 28621.76 & 1.99 & 4.17 & 46.34 \\
\hline $\begin{array}{c}\text { Treatment } \\
\text { (Genotype) }\end{array}$ & 20 & 235.01 & 195.61 & $2 \underset{* * 17}{226.17}$ & $2.56^{* *}$ & $0.04^{* *}$ & $1.88^{* *}$ & $\begin{array}{c}2268.9 \\
1^{* * *} \\
\end{array}$ & $3.43 * *$ & $0.39^{* *}$ & $1.36^{* *}$ & 0.76 & $79537.21^{*}$ & $5.52^{* *}$ & $6.89^{* *}$ & $76.62^{* *}$ \\
\hline Error & 40 & 3.56 & 3.78 & 4.14 & 0.08 & 0.00 & 0.27 & 105.16 & 0.24 & 0.22 & 0.74 & 0.10 & 12904.38 & 0.89 & 4.25 & 47.24 \\
\hline $\mathrm{SEm} \pm$ & & 1.54 & 1.58 & 1.66 & 0.23 & 0.04 & 0.43 & 8.37 & 0.40 & 0.38 & 0.70 & 0.26 & 92.75 & 0.77 & 1.68 & 5.61 \\
\hline
\end{tabular}


Table.2 Mean performance for 15 characters of 21 genotypes of garden pea

\begin{tabular}{|c|c|c|c|c|c|c|c|c|c|c|c|c|c|c|c|c|}
\hline Sl. No. & Genotypes & 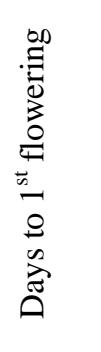 & 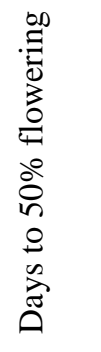 & 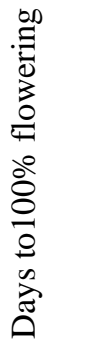 & 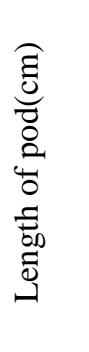 & 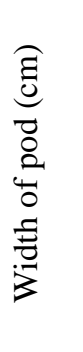 & 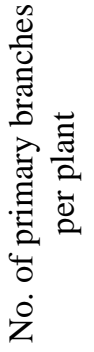 & 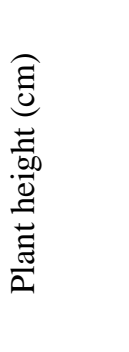 & 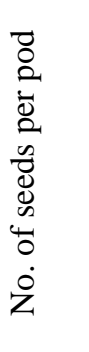 & 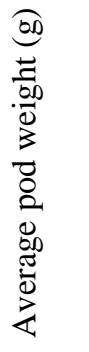 & 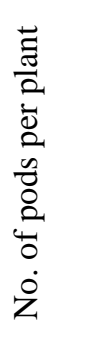 & 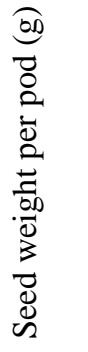 & 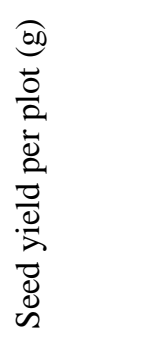 & 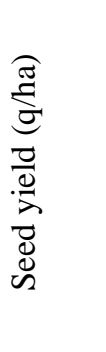 & 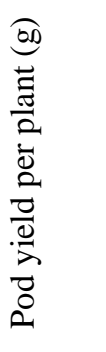 & 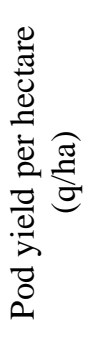 \\
\hline 1 & AP-1 & 55.33 & 60.00 & 65.66 & 9.66 & 1.77 & 3.93 & 61.46 & 8.73 & 5.39 & 10.66 & 2.90 & 1303.00 & 10.85 & 56.85 & 189.52 \\
\hline 2 & PC-531 & 54.33 & 65.00 & 72.33 & 9.68 & 1.48 & 3.33 & 46.00 & 7.93 & 5.69 & 10.13 & 2.63 & 1400.00 & 11.66 & 57.54 & 191.82 \\
\hline 3 & VRP-387 & 53.66 & 59.66 & 63.33 & 8.54 & 1.56 & 4.00 & 70.16 & 6.53 & 5.41 & 10.53 & 2.10 & 1272.00 & 10.60 & 56.95 & 189.85 \\
\hline 4 & VRP-196 & 53.66 & 60.66 & 65.33 & 7.96 & 1.59 & 3.26 & 72.06 & 4.73 & 5.59 & 10.73 & 1.53 & 1707.67 & 14.23 & 59.66 & 198.86 \\
\hline 5 & VRP-174 & 42.00 & 47.66 & 53.66 & 8.43 & 1.52 & 4.46 & 57.46 & 5.60 & 5.67 & 10.06 & 2.20 & 1345.00 & 11.20 & 56.02 & 186.74 \\
\hline 6 & VRP-222 & 41.66 & 54.66 & 63.66 & 6.42 & 1.20 & 3.46 & 68.00 & 5.33 & 5.56 & 10.40 & 1.63 & 1423.33 & 11.86 & 57.82 & 192.73 \\
\hline 7 & VRP-3 & 38.66 & 45.00 & 53.00 & 8.11 & 1.52 & 5.46 & 52.86 & 5.93 & 4.98 & 11.53 & 2.00 & 1375.67 & 11.46 & 57.07 & 190.24 \\
\hline 8 & VRP-48 & 63.33 & 69.33 & 76.33 & 7.57 & 1.48 & 3.20 & 72.80 & 6.93 & 5.23 & 11.40 & 2.00 & 1725.00 & 14.37 & 59.65 & 198.84 \\
\hline 9 & VRP-4 & 42.66 & 54.33 & 62.33 & 7.50 & 1.42 & 3.40 & 64.80 & 6.66 & 5.52 & 10.20 & 2.03 & 1617.33 & 13.48 & 56.37 & 187.91 \\
\hline 10 & VRP-82 & 42.00 & 51.66 & 55.66 & 8.70 & 1.62 & 4.73 & 64.30 & 7.26 & 5.05 & 10.86 & 2.56 & 1539.33 & 12.82 & 54.32 & 181.09 \\
\hline 11 & VRP-284 & 58.66 & 63.00 & 67.00 & 6.96 & 1.46 & 2.80 & 132.00 & 6.13 & 5.87 & 9.80 & 1.70 & 1628.67 & 13.57 & 57.46 & 191.54 \\
\hline 12 & VRP-241 & 57.66 & 64.00 & 71.00 & 7.54 & 1.47 & 3.06 & 72.20 & 5.33 & 5.21 & 11.46 & 2.33 & 1548.00 & 12.90 & 59.80 & 199.34 \\
\hline 13 & VRP-195 & 55.66 & 61.66 & 74.66 & 7.77 & 1.48 & 3.80 & 84.00 & 6.80 & 4.72 & 11.93 & 2.33 & 1527.00 & 12.72 & 55.60 & 185.32 \\
\hline 14 & VRP-61 & 61.00 & 69.00 & 78.00 & 7.22 & 1.32 & 3.40 & 133.36 & 5.73 & 5.67 & 10.20 & 1.03 & 1614.67 & 13.45 & 57.80 & 192.66 \\
\hline 15 & VRP-38 & 36.00 & 42.00 & 50.00 & 7.37 & 1.40 & 2.13 & 49.53 & 4.73 & 6.10 & 9.20 & 1.63 & 1458.00 & 12.15 & 56.10 & 187.00 \\
\hline 16 & VRP-392 & 58.33 & 62.66 & 70.66 & 6.22 & 1.40 & 3.13 & 126.50 & 5.20 & 5.44 & 10.33 & 1.66 & 1706.33 & 14.22 & 56.24 & 187.46 \\
\hline 17 & VRP-248 & 61.66 & 65.66 & 73.66 & 8.71 & 1.55 & 3.00 & 60.00 & 7.73 & 5.72 & 10.06 & 3.13 & 1540.00 & 12.83 & 57.52 & 191.76 \\
\hline 18 & VRP-7 & 67.33 & 72.33 & 81.33 & 8.16 & 1.44 & 2.33 & 45.73 & 6.33 & 6.30 & 9.53 & 1.80 & 1299.00 & 10.82 & 60.04 & 200.13 \\
\hline 19 & VRP-372 & 52.33 & 59.66 & 64.66 & 7.66 & 1.57 & 2.86 & 59.66 & 5.26 & 5.64 & 10.10 & 2.03 & 1887.00 & 15.72 & 56.76 & 189.21 \\
\hline 20 & VRP-299 & 54.33 & 61.33 & 74.33 & 7.87 & 1.52 & 3.00 & 99.46 & 5.60 & 5.61 & 10.33 & 2.46 & 1450.67 & 12.09 & 57.77 & 192.57 \\
\hline 21 & Pant Uphar & 59.66 & 67.66 & 72.66 & 9.21 & 1.34 & 2.60 & 41.53 & 6.53 & 5.73 & 10.36 & 2.60 & 1413.33 & 11.78 & 59.10 & 197.02 \\
\hline$*$ & Grand Mean & 52.86 & 59.86 & 67.11 & 7.97 & 1.48 & 3.40 & 73.04 & 6.24 & 5.53 & 10.47 & 2.11 & 1513.38 & 12.61 & 57.45 & 191.51 \\
\hline$*$ & SEM \pm & 1.09 & 1.12 & 1.18 & 0.17 & 0.03 & 0.30 & 5.92 & 0.18 & 0.27 & 0.50 & 0.19 & 65.59 & 0.55 & 1.19 & 3.97 \\
\hline$*$ & CD at $5 \%$ & 3.12 & 3.21 & 3.36 & 0.48 & 0.09 & 0.87 & 16.92 & 0.81 & 0.78 & 1.42 & 0.54 & 187.05 & 1.56 & 3.40 & 11.34 \\
\hline$*$ & CD at $1 \%$ & 4.17 & 4.29 & 4.50 & 0.64 & 0.13 & 1.17 & 22.64 & 1.08 & 1.03 & 1.91 & 0.72 & 250.84 & 2.09 & 4.55 & 15.18 \\
\hline
\end{tabular}


Table.3 Estimates of range, mean, genotypic and phenotypic coefficient of variation (GCV and PCV), heritability (H), genetic advance (GA) and genetic gain for 15 characters of 21 genotypes of garden pea

\begin{tabular}{|c|c|c|c|c|c|c|c|c|}
\hline $\begin{array}{l}\text { Sl. } \\
\text { No. }\end{array}$ & Character & Range & $\begin{array}{l}\text { Grand } \\
\text { mean }\end{array}$ & GCV & PCV & $\mathrm{H}(\%)$ & GA & $\begin{array}{c}\text { Genetic } \\
\text { Gain }(\%)\end{array}$ \\
\hline 1 & Days to $1^{\text {st }}$ flowering & $36.00-67.33$ & 52.86 & 16.61 & 16.99 & 95.58 & 17.69 & 33.46 \\
\hline 2 & Days to50\% flowering & $42.00-72.33$ & 59.86 & 13.36 & 13.74 & 94.41 & 16.00 & 26.74 \\
\hline 3 & Days to $100 \%$ flowering & $50.00-81.33$ & 67.11 & 12.81 & 13.17 & 94.69 & 17.24 & 25.69 \\
\hline 4 & Length of pod $(\mathrm{cm})$ & $6.23-9.68$ & 7.97 & 11.41 & 11.98 & 90.84 & 1.78 & 22.42 \\
\hline 5 & Width of pod(cm) & $1.21-1.77$ & 1.48 & 7.67 & 8.58 & 79.81 & 0.21 & 14.12 \\
\hline 6 & No. of primary branches per plant & $2.13-5.46$ & 3.40 & 21.54 & 26.55 & 65.83 & 1.22 & 36.00 \\
\hline 7 & Plant height $(\mathrm{cm})$ & $41.53-133.36$ & 73.04 & 36.76 & 39.35 & 87.27 & 51.68 & 70.75 \\
\hline 8 & No. of seeds per pod & $4.73-8.73$ & 6.24 & 16.53 & 18.31 & 81.54 & 1.92 & 30.76 \\
\hline 9 & Average pod weight $(\mathrm{g})$ & $4.72-6.30$ & 5.53 & 4.30 & 9.53 & 20.42 & 0.22 & 4.01 \\
\hline 10 & No. of pods per plant & $9.20-11.93$ & 10.47 & 4.34 & 9.32 & 21.77 & 0.43 & 4.18 \\
\hline 11 & Seed weight per pod $(\mathrm{g})$ & $1.03-3.13$ & 2.11 & 22.14 & 26.95 & 67.46 & 0.79 & 37.46 \\
\hline 12 & Seed yield per plot $(\mathrm{g})$ & $1272-1887$ & 1513.38 & 9.84 & 12.38 & 63.25 & 244.16 & 16.13 \\
\hline 13 & Seed yield (q/ha) & $10.60-15.72$ & 12.61 & 9.84 & 12.38 & 63.25 & 2.03 & 16.13 \\
\hline 14 & Pod yield per plant $(\mathrm{g})$ & $54.33-60.04$ & 57.45 & 1.63 & 3.94 & 17.16 & 0.80 & 1.39 \\
\hline 15 & Pod yield per hectare $(\mathrm{q} / \mathrm{ha})$ & $181.09-200.13$ & 191.51 & 1.63 & 3.94 & 17.17 & 2.67 & 1.39 \\
\hline
\end{tabular}


The PCV and GCV values (> 20\%) were high for plant height, seed weight per pod and number of primary branches per plant. Moderate PCV and GCV values $(10 \%$ - 20\%) was recorded for days to $1^{\text {st }}$ flowering, days to $50 \%$ flowering, days to $100 \%$ flowering and length of pod. Low PCV and GCV (less than 10\%) values have been shown for seed yield per plot, seed yield per hectare, width of pod, numberof pods per plant, average pod weight, pod yield per plant and pod yield per hectare indicating narrow range of variation for these characters and provides very least scope for selection. Similar type of results has also been reported by Lal et al., (2011) and Singh et al., (2012).

Estimates of heritability in broad sense ranged from $17.16 \%$ (pod yield per plant) to $95.58 \%$ (days to $1^{\text {st }}$ flowering). Highest heritability percent was recorded in days to $1^{\text {st }}$ flowering (95.58\%) followed by days to $50 \%$ flowering, days to $100 \%$ flowering, length of pod, width of pod, plant height and number of seeds per pod. The above estimates gave an indication that substantial genetic improvement can be achieved in these characters. Similar kind of results was observed in garden pea for traits like plant height and length garden pea pods by Gupta et al., (2006) and Kumariet al., (2009). High heritability does not mean a high genetic advance for a particular quantitative character. Johnson et al., (1955) reported that heritability estimated along with genetic advance would be more rewarding than heritability alone in predicting the consequential effect of selection to choose the best individual.

High heritability and moderate genetic gain was observed for characters like days to $50 \%$ flowering, days to $100 \%$ flowering, length of garden pea pods and width of garden pea pods. This indicates the influence of non additive gene action and environment in the expression of these traits which are less reliable for direct selection in crop improvement. So, breeder should adopt proper methods to utilize both additive and non additive gene effects simultaneously. This highlights the fact that in variability studies one should not rely upon phenotype alone while making selection it is always better to consider PCV, GCV and high heritability coupled with high genetic gain. Hence, the breeder should adopt suitable breeding methodology to utilize both additive and non-additive gene effects simultaneously since varietal and hybrid development will go a long way in the breeding programmes.

\section{References}

Johnson, H.W., Robinson, H.F. and Comstock, R.E.1955. Estimates of genetic and environmental variability of soybean. Agronomy J., 47: 314-318.

Lush, J.L. 1949.Intersize correlation, regression of offspring on dams as a method of estimating heritability of characters. Proceeding American Society of Animal. Proc., 33: 293301.

Burton, G.W. 1952. Quantitative inheritance in grasses.Proc. $6^{\text {th }}$ Int. Grassland Cong., 1: 227-283.

Gupta, A.J. and Singh, Y.V. 2006.Genetic divergence study in garden pea (PisumsativumL.).Indian J. Genet.and Pl. Breed., 66: 341-342.

Kumari, N., Srivastava, J.P. and Singh, B. 2009.Heritability and genetic advance in vegetable pea (PisumsativumL.). Ann. Hort. 2(2): 224-225.

Lal, G.M., Meena, M.L. and Kunj, C.M. 2011. Assessment of genetic variability and interrelation between yield and its contributing components in field pea (PisumsativumL.). Env. Eco., 29(3A): 12351239.

Singh, M., Malik, S., Singh, M.K., Kumar, K.V.S., Dev, P. and Kumar, V. 2012. Studies of variability, heritability and genetic advance in field pea (PisumsativumL.). Prog. Agric., 12(1): 219-222.

\section{How to cite this article:}

Sana Afreen, Anand Kumar Singh, Durga Prasad Moharana, Vaibhav Singh, Pushpendra Singh and Bhagat Singh. 2017. Genetic Evaluation for Yield and Yield Attributes in Garden pea (Pisumsativumvar.hortense L.) under North Indian Gangetic Plain Conditions. Int.J.Curr.Microbiol.App.Sci. 6(2): 1399-1404. doi: http://dx.doi.org/10.20546/ijcmas.2017.602.158 